\title{
Recovery of Coal Values from Middling and Rejects by Froth Flotation and Mozley Mineral Separation
}

\author{
Reuben J. Mdoe ${ }^{1}$ \& Anand Anupam ${ }^{2}$ \\ ${ }^{1}$ Master of Technology in Fuel Engineering, IIT(ISM) Dhanbad, India \\ ${ }^{2}$ Assistant Professor, IIT(ISM), Dhanbad, India \\ Correspondence: Reuben J. Mdoe, Master of Technology in Fuel Engineering, IIT(ISM) Dhanbad, India.
}

Received: March 24, $2021 \quad$ Accepted: April 17, $2021 \quad$ Online Published: June 18, 2021

doi:10.11114/set.v8i1.4785 URL: https://doi.org/10.11114/set.v8i1.4785

\begin{abstract}
The recovery of coals values from Middling and Rejects carries out by using Froth flotation and Mozley Mineral Separation. The middling and rejects are the waste products from gravity beneficiation process, it has been noted that most of washery plants are selling this product at low cost because they have less values.

The independent variables selected for Mozley Mineral Separator and their ranges were indicated in the parentheses as follow, water flow rates $(400,600,800 \mathrm{ml} / \mathrm{s})$, amplitude $(1.25,1.5,1.75 \mathrm{inch})$ and collection time $(30,40,60 \mathrm{~s})$ while the independent variables for froth flotation were; Pulp density $(10,12.5,15 \%)$, collector dosage $(39.3,44.4,49.5 \mathrm{~g} / \mathrm{t}) \mathrm{and}$ frother dosage $(61.8,65.3,68.8 \mathrm{~g} / \mathrm{t})$. The number of experimental runs and regression equation determined by using Design Expert software

The $\mathrm{d}_{80}$ for middling and rejects samples were $10.5 \mathrm{~mm}$ and $12.89 \mathrm{~mm}$ respectively. The ash contents for the middling sample treated by froth flotation decrease from $37 \%$ to $15.85 \%$ at the reagent concentration of $49.5 \mathrm{~g} / \mathrm{t}$ collector, $65.3 \mathrm{~g} / \mathrm{t}$ frother and pulp density of $10 \%$. The froth flotation results of middling sample shown to have a great reduction of ash contents. The overall optimum middling recovery and yield for washery grade I and II attain at reagent concentration and pulp density of $47.703 \mathrm{~g} / \mathrm{t}, 68.568 \mathrm{~g} / \mathrm{t}$ and $13.2 \%$ for collector, frother and pulp density respectively. The feed of reject coal was $71 \%$ and the ash contents reduced to $28.87 \%$ with the recovery of $0.85 \%$. The analysis through Mozley mineral separator did not show significant changes in the reduction of ash from both middling and rejects. The ash contents achieved were above the scope of the studies for recovering of coal values. The experiments for middling and reject by froth flotation and Mozley mineral separator may be carried out by varying other parameters as well as the type of methods.
\end{abstract}

Keywords: Recovery, Middling, Reject, Froth Flotation, Mozley Mineral Separator and Yield

\section{Introduction}

Coal is complex mixture of plant substances which altered in varying degree of alteration by physical and chemical processes. The process of changing plants into coal occurred in million years ago, it was facilitated by the presence of bacteria, heat, and pressure inside the earth crust and consists mainly of carbon and other volatile matters. Indian coals formed due to drift theory. (Gupta, 1990).

The Energy statistical data of 2018 reveals that the raw coal consumption in India industries increases from 502.82 MT during 2007-2008 to 841.56 MT in 2016 - 2017. Also, it was shown that the major coal consumptions are electricity generation (527.26 MT), steel and washeries industries (54.15 MT), cement industries (6.43 MT) and sponge iron industries (5.68 MT) as per data released in 2016 - 2017. In 2013 India's electricity sector consumed about $72 \%$ of the coal produced in the country (Energy statistical data 2018 twenty-fifth issues retrieved 8/08/2018).

The coal washeries in India were introduced in 1951 by Tata steels, to date varies plants have been commissioned. The ash contents of the Indian coal ranging from 25 to $35 \%$ while the ash required for thermal industries should be less than $17 \%$ and not more than $18 \%$ as prescribed by Indian Standards. In order to meet the above requirements coal washeries are forced to produce coal of $14-17 \%$ ash contents with the yield of $35-45 \%$ (Dash 2015). 


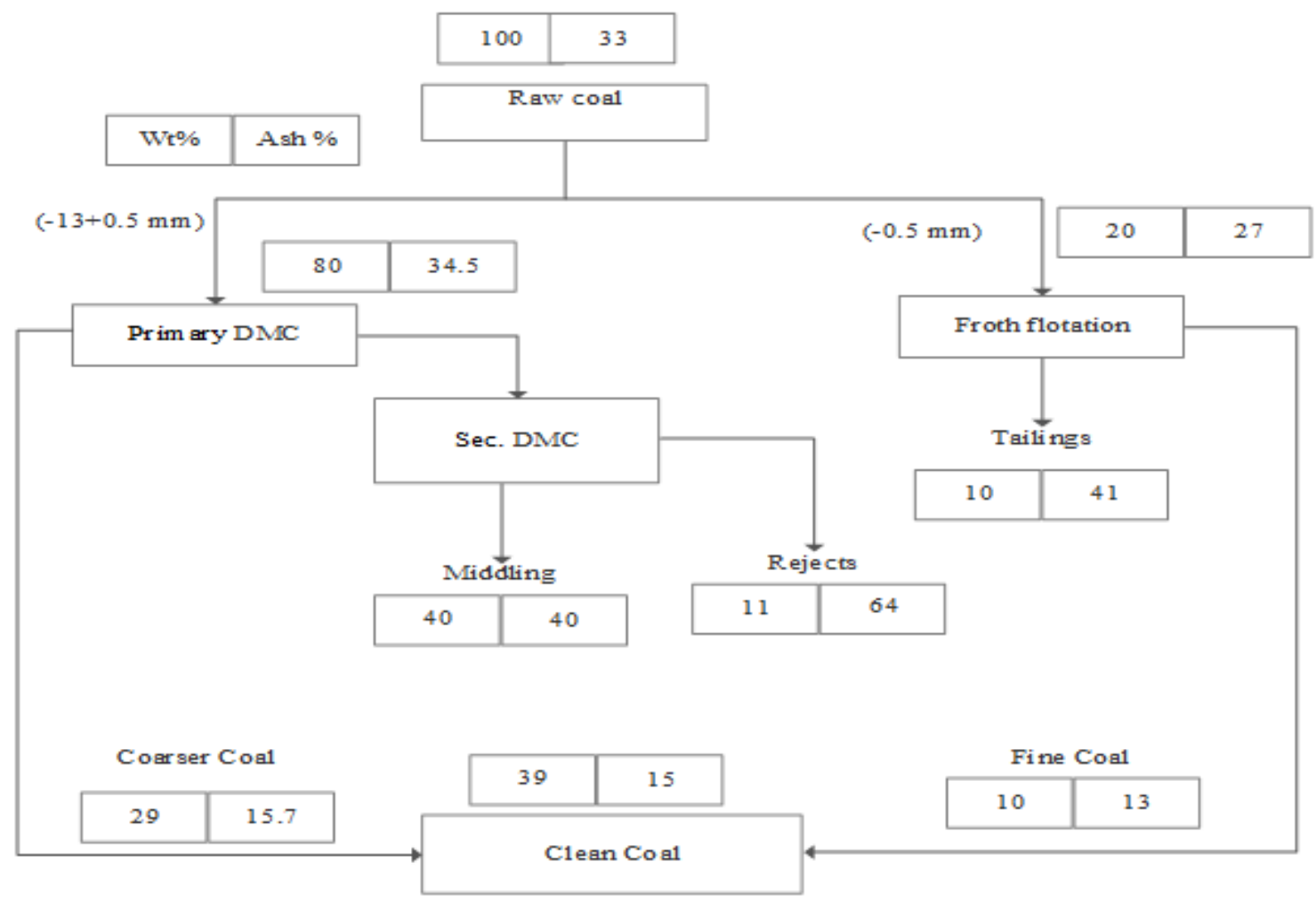

Figure 1. Coal beneficiation technique flow chart

The ash contents of middling and reject are ranging from $30-45 \%$ and $65-80 \%$ respectively, due to high ash contents most of washeries sells to the thermal power plants or mixing with low ash coals. In order to recovery coal values from middling and rejects should have to be ground and subjected to other beneficiation methods such as froth flotation or mozley gravity Separation. Some of washeries have tried to recover coals by froth flotation but still the processes have proven to be inefficient due to lack of capital and poor knowledge of the process. Few researches have been performed for utilization of Column flotation but also it seems that its operation is not economical due to high quantity of reagents and need skilled personnel to operate. Mozley and Conventional froth flotation have been used throughout of these study as the alternative methods of recovery coal values from middling and reject at the specified parameters. Recently, a new gravity based technology, termed as Multi Gravity Separator (MGS) has been introduced into the current market which may eliminate the problem of recovery of fines coal fractions (Traore, et al 1995).

India coal reserve has been depleted due to the rapid increases of uses, which results the mining and process mechanization to be modified. Therefore, as the increases in coal mining technology, more coals fines are generated, which results to higher economic loss and the environmental pollutions. Moreover, in the old technology beneficiation, the fine coal tailings were commercially concentrated by using equipment such as, Denser Medium Cyclone (DMC), Spirals, Shaking tables and froth flotations (Luttrell et al, 1994, Luttrell et al, 1995, Rao and Bandopadhyay, 1992). Conversely, the processing of fine coal fraction is very difficult as it requires high running cost at the lowest recovery with a high moisture content of the final products.

According to the nature of Indian coal (drift origin) both low ash and high yield cannot be attained at a time through physical beneficiation route. The low yield is mainly contributed by poor liberation (Suresh, 2015). Most of washeries techniques depends on liberation characteristics and surface properties. Apart from that, the washability characteristics of Indian coal are very poor because of having higher near gravity material. Elsewhere, the physical beneficiation cannot be replaced by chemical ways due to high cost of the process of waste handling. 


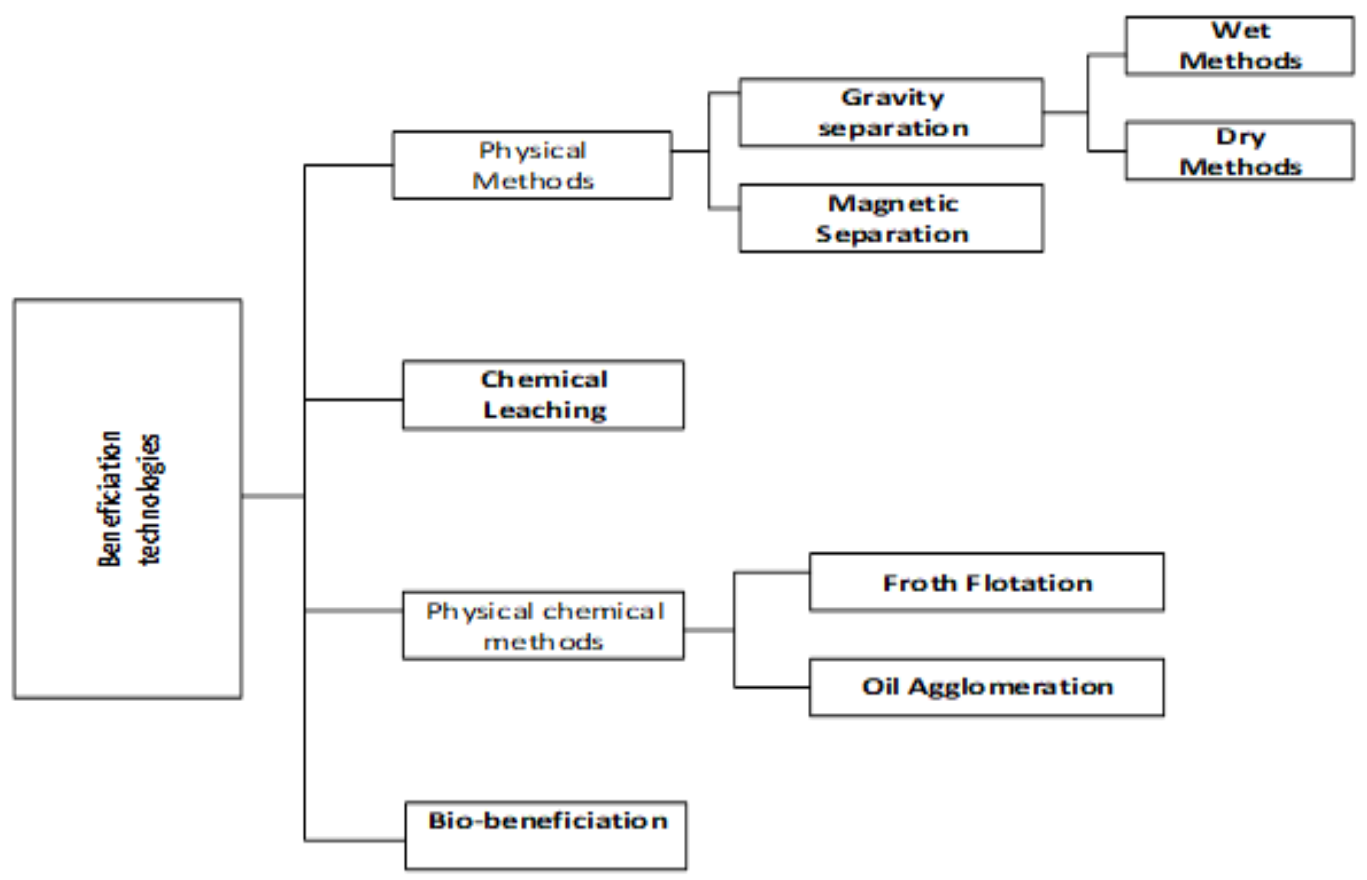

Figure 2. Classification of low-rank coal beneficiation techniques

\section{Froth Flotation}

Froth flotation is the beneficiation method for the recovery of valuable solid components from worthless or less valuable solids based on the difference in the surface properties of the various materials. The factors which affecting the froth flotation process are particle size, reagent concentration, pulp density, nature of impurities, macerals and ranking. The amount of adhesion of oil droplets into low rank coal and use oily alone is not effective. The operating parameters are interrelated. Some affect grade and other affect both recovery and grade, it has been established that frother affect grade while air flow rate affects recovery. (Reddy,2000)

\section{Particle size}

The froth flotation of coal is directly related to the percentage of coal surface available for bubble attachment and inversely related to the particle mass. It is affected by both particle mass and the coal surface available for bubble attachment and can be expressed by the following relationship

$$
F \propto \frac{f(f x)}{g(m)}
$$

Where $\mathrm{F}=$ particle flotation rate, $\mathrm{f}(\mathrm{x})=\mathrm{a}$ function of particle surface, and $\mathrm{g}(\mathrm{m})=\mathrm{a}$ function of the particle mass. This expression shows that the particle flotation rate increases with an increase in the coal surface, $x$, and with a decrease in particle mass, $\mathrm{m}$.

\section{Reagent Concentration}

Zimmerman (1964) analyzed that coal flotation is desirable for the addition of both frother and collector together, such as an alcohol and kerosene/fuel oil. Frother additional should vary from 45 to $227 \mathrm{~g} /$ ton of feed and collector may vary from 227 to $910 \mathrm{~g}$ /ton of feed.

According to Laros (1977), the treatment of coal with Methyl Isobutyl Carbinol (MIBC) gives the best ash and total sulfur removal out of six commercial frother tested, even though MIBC appeared to exhibit a collector-like property. Miller (1975) illustrated that MIBC is powerfully reagent compared to any other types of frother such as pine oil or water-soluble polyglycol types.

\section{Pulp density}

Another major controllable parameter in froth flotation is pulp density, it is affects the volume of material processed, it also determines the residence time for a solid material in a conditioning tanks and flotation cells/column. Subsequently, most of froth flotation reagents are dosed on the basis of a gram per ton of solid, therefore the pulp density defines the reagent consumption. Decker (1956.) illustrated that the good results are obtained when the pulp density is approximate $20 \%$ by weight. Furthermore, the Brown (1962) stated that the pulp density of coal flotation varies from 6 to $25 \%$, 
depending on coal rank, type, and ash content. In the United States, the pulp density of coal flotation varies from 3 to $20 \%$, or an average of about $7 \%$. Also, Davis (1948) mentioned that $8 \%$ solids are the maximum desirable pulp density for coal flotation.

\section{Moisture Content}

Moisture is the loss of mass during drying of a sample and it is reported in percentage. Water present in coal will results into decrease of heat content per $\mathrm{kg}$, as it replaces the combustible matters. Moisture contents in a percentage of analyzed sample can be calculated as follows:

$$
\text { Moisture in analysis sample }(\%)=\frac{W_{2}-W_{3}}{W_{2}-W_{1}} X 100
$$

$\mathrm{W}_{1}$ is the weight of empty watch glass, $(\mathrm{gm}), \mathrm{W}_{2}$ is the weight of the watch glass and coal sample before heating, (gm), and $\mathrm{W}_{3}$ is the weight of the watch glass and sample after heating.

\section{Coal ash}

Coal ash is the waste that remains after burning coal in the presence of air. It includes fly ash (fine powdery particles that are carried up by the smokestack and captured by pollution control devices) as well as coarser materials that fall to the bottom of the furnace. It is noncombustible inorganic remains after burning of coal, it includes an inorganic matter which composes clay minerals, silt particles of quartz, carbonate, iron oxide and Sulphur compounds.

The formula for ash percentages is:

$$
\text { Ash in analysis sample }(\%)=\frac{W_{3}-W_{1}}{W_{2}-W_{1}} \times 100
$$

Where, $\mathrm{W}_{1}$ is the weight of empty ash crucible, $(\mathrm{gm}), \mathrm{W}_{2}$ is the weight of the ash crucible and coal sample before heating, (gm) and $\mathrm{W}_{3}$ is the weight of the ash crucible and sample after heating.

\section{Volatile Matter}

Volatile matters are unwanted inorganic, organic materials (apart from carbon), and incombustible gases such as carbon dioxide and nitrogen which are found in coal, this means that the volatile matter is an index of the gaseous fuels present in the coal, it is ranging from 20 to 35\%. (Bureau of Energy Efficiency)

Mathematically can be defined as the percentage of loss in mass with respect to the original mass and can be expressed as follows:

$$
\text { Volatile matter in analysis sample }(\%)=\left[\frac{W_{2}-W_{3}}{W_{2}-W_{1}} X 100\right\rceil-\% M
$$

Where, $\mathrm{W}_{1}$ is the weight of empty platinum crucible with lid, $(\mathrm{gm}), \mathrm{W}_{2}$ is the weight of the platinum crucible with lid and coal sample before heating, $(\mathrm{gm}), \mathrm{W}_{3}$ is the weight of the platinum crucible with lid and sample after heating and $\mathrm{M}$ is stands for the percentage moisture in the sample on air-dried basis.

\section{Fixed Carbon}

Fixed carbon is the percentage of carbon present in a coal, it is determined by removing the percentages of ash, moisture, and volatile matter from the coal sample. Fixed carbon is the estimated amount of coke that will be yielded from the coal.

The percentage of fixed carbon can be calculated by deducting the summation of moisture percentage, ash percentage and volatile matter percentage from 100 .

$$
\% F C=100-(\% M+\% A+\% V M)
$$

Where, $\mathrm{FC}$ is the fixed carbon in percentage, $\% \mathrm{M}$ is the moisture percentage, $\% \mathrm{~A}$ is the ash percentage and $\% \mathrm{VM}$ is the percentage of volatile matter.

\section{Combustible recovery calculations}

$$
\text { Combustible recovery }(\%)=\frac{M_{c}\left(1-A_{c}\right)}{F_{f}\left(1-A_{f}\right)} \times 100 \text { or } R c=\frac{Y c c\left(100-A_{c}\right)}{100-A_{f}}
$$

Where $A_{c}$ ash content of clean coal, $A_{f}$ ash content of the feed, $M_{c}$ mass of clean coal, $Y_{c c}$ Yield of combustible, $R_{c}$ Recovery of combustible and $M_{f}$ mass of feed. 
Ash rejection is equal to the recovery of non-combustible in reject in two products system and can be calculated as follows:

$$
\begin{gathered}
R_{N C}^{R}=\frac{\text { Wt of } N_{c} \text { in Reject }}{\text { Wt of } N_{c} \text { in Feed }} \times 100 \\
\text { Ash of reject }=\frac{Y_{R J} \times A_{r}}{A_{f}}
\end{gathered}
$$

Where $R_{N C}^{R}$ the recovery of non-combustible in reject, $Y_{R J}$ Yield of reject, and $N_{C}$ is non-combustible.

Recovery of non-combustible can be calculated by the following numerical

$$
R_{N C}=\frac{Y_{c c} x A_{C}}{A_{f}}
$$

Where $R_{N C}$ is recovery of Non- Combustible and $Y_{c c}, \mathrm{~A}_{\mathrm{c}}$ and $A_{f}$ are Yield of clean coal, Ash of clean coal and ash of feed respectively.

\section{Material and Methodology}

The study has focused on finding the best recovery technique which will enhance productivity in the washery plants. The research has intended to recover the coal values from middling and rejects by using Mozley Mineral Separator and Froth Flotation.

The particles size and reagents dosages were varied in the flotation analysis, while wash flow rate, oscillation amplitude, and duration of oscillation were varied in the Mozley Mineral Separator.

40kg of each Middling and Rejects samples were taken from Bhelatand Coal Preparation Plant, and kept in separate two bags for further studies. Then, from each bag $1 \mathrm{~kg}$ representative sample was taken as the head sample. In order to know the behavior of the coal sample, the following experiments were determined: Proximate Analysis, Ultimate analysis, Gross calorific values, Low Temperature Gray King Assay (LTGK) and free swelling Index (FSI).

The reserve sample (20kgs approx.) was subjected to cone and quartering for sample division, four (4) samples of approximate $5 \mathrm{kgs}$ each were collected and distributed as follows:

First sample was crushed by using roller crusher followed by sieving to $-0.5 \mathrm{~mm}$, the undersize particles were collected and kept properly in a bag for further studies on froth flotation experiments. Second sample was also crushed by using roller crusher, followed by sieving to the following size ranges:

$$
\begin{aligned}
& \text { 1. }-2 \mathrm{~mm}+0.5 \mathrm{~mm} \\
& \text { 2. }-1 \mathrm{~mm}+0.5 \mathrm{~mm} \\
& \text { 3. }-1 \mathrm{~mm}+0.075 \mathrm{~mm} \\
& \text { 4. }-0.5 \mathrm{~mm}+0.075 \mathrm{~mm}
\end{aligned}
$$

The samples which were collected above were used for Mozley Mineral Separation experiments.

Third sample was subjected to sieve size analysis for the determination of $\mathrm{p} 80$, and the finally portion of sample was sealed and kept in laboratory as reserves sample. The above procedures were repeated for both Middling and Rejects.

\section{Material and equipment}

Muffle furnace was used for ash and Volatile Matter analysis, while Air dry oven for moisture analysis and LTGK was performed in Horizontal Electrical Arc Furnace with a tube of $20 \mathrm{gms}$ capacity. Froth flotation experiments were carried out at Denver Laboratory Flotation Machine with 2L cell. On the other hand, Mozley Mineral separator was utilized for gravity beneficiation analysis. Different sieves and screens were used for size analysis while beaker and glass rod for Mozley sample mixing.

\section{Test Procedures}

\section{Froth Flotation}

About $5 \mathrm{~kg}(-0.5 \mathrm{~mm})$ of representative coal sample was subsampled by cone and quartering method where 16 samples of around $300 \mathrm{gms}$ were collected, one portion was crushed to $-72 \mathrm{mesh}$ for sample characterization. The other portions were subjected to froth flotation experiments. Collector, frother doses and pulp density were chosen as the variables for froth flotation. According to Box and Behenken when there are three variables selected, need to perform 15 runs with 3 center points included. The specific gravity of coal determined by using pycnometer while the reagents calculated by using specific gravity bottle. 
$2 \mathrm{~L}$ of flotation cell was selected for the experiment and reagents were varied accordingly. The variables for this study were $(39.3,44.4$, and $49.5 \mathrm{~g} / \mathrm{t}),(61.8,65.3$, and $68.8 \mathrm{~g} / \mathrm{t})$ and $(10,12.5$ and $15 \%)$ for collector dosage, frother dosage and pulp density respectively.

The pulp was thoroughly agitated for 5 minutes, followed by collector dosage and conditioned for another 5 minutes. Then, frother was dosed and immediately the concentrates (clean coal) ware skimmed with the interval of 10seconds for duration of 2 minutes each clean coal collected within these intervals were kept in separate trays.

The concentrates (clean coal) and tailings were dried in oven, the temperature adjusted to $105^{\circ} \mathrm{C}$. The weight of each portion were collected followed by crushing and sieving to -72 mesh and finally, the ash contents were determined. These procedures were repeated for both middling and reject samples.

\section{Mozley Mineral Separator}

Each size fractions which were collected earlier were subjected to conning and quartering whereas, 16 representative samples of each having $30 \mathrm{gms}$ approximate were collected and kept in separate bags. One portion from each size range was further crushed to -72 mesh size for coal sample characterization.

Parameters and ranges for Mozley mineral separation were: Water flow rate (400,600 and $800 \mathrm{ml} / \mathrm{min})$, Amplitude (2.5, 3.0 and 3.5rpm) and wash time (30,45 and 60 seconds).

Coal sample was mixed thoroughly by swirling with glass rod until a uniform mixture was formed. Then after, the sample was poured slowly into a Mozley tray for 1 minute. Furthermore, the coal sample was allowed to flow in a tray for selected wash time. After wash time achieved the machine (Mozley Mineral Separator) switched off, followed by collecting clean and rejects coals. Lastly the sample collected were kept inside the oven and the temperature adjusted to $105^{\circ} \mathrm{C}$ for drying, after drying the weight and ash contents were determined. 15 runs were performed which includes 3 center points. These procedures were repeated for both middling and reject samples.

\section{Results}

Table 1. Characterization of head sample

\begin{tabular}{|c|c|c|c|c|c|c|c|c|}
\hline \multicolumn{9}{|c|}{ Head Sample Characterization } \\
\hline & & \multicolumn{4}{|c|}{ Middling Sample } & \multicolumn{3}{|c|}{ Reject Sample } \\
\hline \multirow{2}{*}{\multicolumn{2}{|c|}{$\begin{array}{l}\text { Moisture } \\
\text { Volatile matter }\end{array}$}} & \multicolumn{4}{|c|}{$0.64 \%$} & \multicolumn{3}{|c|}{$0.5 \%$} \\
\hline & & \multicolumn{4}{|c|}{$16.64 \%$} & \multicolumn{3}{|c|}{$15.02 \%$} \\
\hline \multicolumn{3}{|l|}{ Ash } & \multicolumn{3}{|c|}{$34.20 \%$} & \multicolumn{3}{|c|}{$71.81 \%$} \\
\hline \multicolumn{6}{|l|}{ Free swelling index } & \multicolumn{3}{|c|}{1.00} \\
\hline \multicolumn{6}{|c|}{ Low Temperature Gray King Assay } & \multicolumn{3}{|l|}{ A } \\
\hline \multicolumn{6}{|l|}{ Pulp Volume } & \multicolumn{3}{|c|}{$2000 \mathrm{cc}$} \\
\hline \multirow{2}{*}{\multicolumn{9}{|c|}{$\begin{array}{l}\text { Weight of Sample } \\
\text { The characterization of Head sample for both middling and reject coal. }\end{array}$}} \\
\hline & & & & & & & & \\
\hline \multicolumn{9}{|c|}{ Table 2. Regression analysis of middling coal for washery grade II ( $24 \%$ Ash) } \\
\hline \multicolumn{9}{|c|}{ Washery grade II (24\% Ash) } \\
\hline & \multirow{2}{*}{$\begin{array}{l}\text { Yield(\%) } \\
\text { Coefficient }\end{array}$} & \multicolumn{3}{|c|}{ Recovery (\%) } & \multicolumn{2}{|c|}{ Separation Efficiency (\%) } & \multicolumn{2}{|c|}{ Yield Reduction factor } \\
\hline & & p-value & Coefficient & $\begin{array}{l}\mathrm{p}- \\
\text { value }\end{array}$ & Coefficient & p-value & Coefficient & p-value \\
\hline Constant & 27.85 & 0.013 & 33.92 & 0.013 & 16.14 & 0.013 & 20.04 & 0.013 \\
\hline $\mathrm{X}_{1}$-Collector & -3.27 & 0.14 & -3.98 & 0.14 & -1.90 & 0.14 & 0.909 & 0.14 \\
\hline $\mathrm{X}_{2}$-Frother $\quad(\mathrm{g} / \mathrm{t})$ & -2.03 & 0.327 & -2.47 & 0.327 & -1.17 & 0.327 & 0.563 & 0.327 \\
\hline $\mathrm{X}_{3}$-Pulp d & -2.83 & 0.19 & -3.45 & 0.19 & -1.64 & 0.19 & 0.787 & 0.19 \\
\hline $\mathrm{X}_{1} \mathrm{X}_{2}$ & -4.18 & 0.174 & -5.09 & 0.174 & -2.42 & 0.174 & 1.16 & 0.174 \\
\hline $\mathrm{X}_{1} \mathrm{X}_{3}$ & 6.96 & 0.047 & 8.47 & 0.047 & 4.03 & 0.047 & -1.93 & 0.047 \\
\hline $\mathrm{X}_{2} \mathrm{X}_{3}$ & -13.80 & 0.003 & -16.81 & 0.003 & -8.00 & 0.003 & 3.83 & 0.003 \\
\hline $\mathrm{X}_{1}^{2}$ & -5.25 & 0.114 & -6.40 & 0.114 & -3.04 & 0.114 & 1.46 & 0.114 \\
\hline $\mathrm{X}_{2}^{2}$ & 1.39 & 0.636 & 1.69 & 0.636 & 0.8054 & 0.636 & -0.386 & 0.636 \\
\hline $\mathrm{X}_{3}^{2}$ & -15.63 & 0.002 & -19.03 & 0.002 & -9.06 & 0.002 & 4.34 & 0.002 \\
\hline$\overline{\mathrm{R}^{2}}$ & 0.9420 & & 0.9420 & & 0.9420 & & 0.9420 & \\
\hline Adj $R^{2}$ & 0.8375 & & 0.8375 & & 0.8375 & & 0.8375 & \\
\hline
\end{tabular}

When $\mathrm{p}$ - values are less than 0.05 indicates that the model is significant. The table above shows that $\mathrm{AC}, \mathrm{BC}$ and $\mathrm{C}^{2}$ are significant model terms. The level of significant can be defined by $1 \%, 5 \%$ and $10 \%$ which corresponds to $99 \%, 95 \%$ and $90 \%$ respectively. When p-values are greater than 0.1 implies that the mode is not significant or rejected. 
The equations below give the relationship between input variables such as Collector, Frother, Pulp density against Yield (\%), Recovery (\%), Separation Efficiency (\%) and Yield Reduction Factor

Regression equations

Yield $(\%)=27.85-3.27 X_{1}-2.03 X_{2}-2.83 X_{3}-4.18 X_{1} X_{2}+6.96 X_{1} X_{3}-13.80 X_{2} X_{3}-5.25 X_{1}^{2}+1.39 X_{2}^{2}-$ $15.63 X_{3}^{2} \quad \mathrm{R} 2=0.942$

Recovery $(\%)=33.92-3.98 X_{1}-2.47 X_{2}-3.45 X_{3}-5.09 X_{1} X_{2}+8.47 X_{1} X_{3}-16.81 X_{2} X_{3}-6.4 X_{1}^{2}+1.69 X_{2}^{2}-$ $19.03 X_{3}^{2} \mathrm{R}^{2}=0.94$

Separation Efficiency $(\%)=27.85-3.27 X_{1}-2.03 X_{2}-2.83 X_{3}-4.18 X_{1} X_{2}+6.96 X_{1} X_{3}-13.80 X_{2} X_{3}+$ $1.46 X_{1}^{2}+1.39 X_{2}^{2}-15.63 X_{3}^{2} \mathrm{R} 2=0.942$

Yield Reduction Factor $=20.04+0.909 X_{1}+0.563 X_{2}+0.7872 X_{3}+1.16 X_{1} X_{2}-1.93 X_{1} X_{3}+3.83 X_{2} X_{3}-$ $6.4 X_{1}^{2}-0.386 X_{2}^{2}-4.34 X_{3}^{2} \quad \mathrm{R}^{2}=0.942$

Table 3. Regression analysis for middling coal from washery grade I (21\% Ash)

\begin{tabular}{|c|c|c|c|c|c|c|c|c|}
\hline \multicolumn{9}{|c|}{ Washery grade I (21\% Ash) } \\
\hline & \multicolumn{2}{|l|}{ Yield(\%) } & \multicolumn{2}{|c|}{ Recovery (\%) } & \multicolumn{2}{|c|}{ Separation Efficiency (\%) } & \multicolumn{2}{|c|}{ Yield Reduction factor } \\
\hline & Coefficient & p-value & Coefficient & $\mathrm{p}$-value & Coefficient & p-value & Coefficient & p-value \\
\hline Constant & 16.33 & 0.233 & 20.68 & 0.233 & 11.56 & 0.233 & 23.24 & 0.233 \\
\hline $\mathrm{X}_{1}-$ Collector $(\mathrm{g} / \mathrm{t})$ & 0.5 & 0.678 & 0.633 & 0.678 & 0.354 & 0.678 & -0.139 & 0.678 \\
\hline $\mathrm{X}_{2}$-Frother $\quad(\mathrm{g} / \mathrm{t})$ & 0.25 & 0.833 & 0.317 & 0.833 & 0.177 & 0.833 & -0.069 & 0.833 \\
\hline $\mathrm{X}_{3}$-Pulp d $\quad(\%)$ & -0.75 & 0.546 & -0.95 & 0.546 & -0.531 & 0.546 & 0.208 & 0.546 \\
\hline $\mathrm{X}_{1} \mathrm{X}_{2}$ & -1.5 & 0.286 & -1.9 & 0.286 & -1.06 & 0.286 & 0.417 & 0.286 \\
\hline $\mathrm{X}_{1} \mathrm{X}_{3}$ & -4.0 & 0.157 & -5.06 & 0.157 & -2.83 & 0.157 & 1.11 & 0.157 \\
\hline $\mathrm{X}_{2} \mathrm{X}_{3}$ & 0.75 & 0.546 & 0.95 & 0.546 & 0.531 & 0.546 & -0.208 & 0.546 \\
\hline $\mathrm{X}_{1}^{2}$ & -3.04 & 0.146 & -3.85 & 0.146 & -2.15 & 0.146 & 0.845 & 0.146 \\
\hline $\mathrm{X}_{2}^{2}$ & -0.792 & 0.607 & -1.0 & 0.607 & -0.56 & 0.607 & 0.22 & 0.607 \\
\hline $\mathrm{X}_{3}^{2}$ & 2.21 & 0.234 & 2.8 & 0.234 & 1.56 & 0.234 & -0.613 & 0.234 \\
\hline $\mathrm{X}_{1} \mathrm{X}_{2} \mathrm{X}_{3}$ & 60.36 & 0.28 & 76.42 & 0.28 & 42.71 & 0.28 & -16.77 & 0.28 \\
\hline $\mathrm{X}_{1}^{2} \mathrm{X}_{2}$ & -3.75 & 0.126 & -4.75 & 0.126 & -2.65 & 0.126 & 1.04 & 0.126 \\
\hline $\mathrm{X}_{1}^{2} \mathrm{X}_{3}$ & 0.750 & 0.753 & 0.9495 & 0.753 & 0.531 & 0.753 & -0.208 & 0.753 \\
\hline $\mathrm{R}^{2}$ & 0.9567 & & 0.9567 & & 0.957 & & 0.9567 & \\
\hline$\overline{\mathrm{Adj}} \mathrm{R}^{2}$ & 0.6967 & & 0.6967 & & 0.6967 & & 0.6967 & \\
\hline
\end{tabular}

Regression equations:

Yield $(\%)=16.33+0.5 X_{1}+0.25 X_{2}-0.75 X_{3}-1.5 X_{1} X_{2}-4.0 X_{1} X_{3}+0.75 X_{2} X_{3}-3.04 X_{1}^{2}-0.792 X_{2}^{2}+2.21 X_{3}^{2}+$ $60.36 X_{1} X_{2} X_{3}-3.75 X_{1}^{2} X_{2}+0.75 X_{1}^{2} X_{3} \quad \mathrm{R}^{2}=0.9567$

Recovery $(\%)=20.68+0.633 X_{1}+0.317 X_{2}-0.95 X_{3}-1.9 X_{1} X_{2}-5.06 X_{1} X_{3}+0.95 X_{2} X_{3}-3.85 X_{1}^{2}-X_{2}^{2}+$ $2.8 X_{3}^{2}+76.42 X_{1} X_{2} X_{3}-4.75 X_{1}^{2} X_{2}+0.9495 X_{1}^{2} X_{3} \quad \mathrm{R}^{2}=0.9567$

Separation Efficiency $(\%)=11.56+0.354 X_{1}+0.177 X_{2}-0.53 X_{3}-1.06 X_{2}-2.83 X_{1} X_{3}+0.53 X_{2} X_{3}-$ $2.15 X_{1}^{2}-0.56 X_{2}^{2}+1.56 X_{3}^{2}+42.71 X_{1} X_{2} X_{3}-2.65 X_{1}^{2} X_{2}+0.53 X_{1}^{2} X_{3} \quad \mathrm{R}^{2}=0.9567$

Yield Reduction Facto $=23.24-0.139 X_{1}-0.069 X_{2}+0.208 X_{3}+0.417 X_{2}+1.11 X_{1} X_{3}-0.208 X_{3}+0.845 X_{1}^{2}+$ $0.22 X_{2}^{2}-0.613 X_{3}^{2}-16.77 X_{1} X_{2} X_{3}+1.04 X_{1}^{2} X_{2}-0.208 X_{1}^{2} X_{3} \quad \mathrm{R}^{2}=0.9567$

Table 4. Optimum recovery of middling by froth flotation

\begin{tabular}{|c|c|c|c|c|c|c|c|c|c|c|}
\hline \multirow{2}{*}{$\frac{\text { Parameters }}{\text { Collector }}$} & \multirow[b]{2}{*}{$\begin{array}{l}\text { Frother } \\
\mathrm{g} / \mathrm{t}\end{array}$} & \multirow[b]{2}{*}{$\begin{array}{l}\text { Pulp Density } \\
5\end{array}$} & \multicolumn{4}{|c|}{ Washery grade II (24\% ash) } & \multicolumn{4}{|c|}{ Washery grade I (21\% ash) } \\
\hline & & & $\begin{array}{l}\text { Yield } \\
\%\end{array}$ & $\begin{array}{l}\mathrm{RC} \\
\%\end{array}$ & $\begin{array}{l}\text { SE } \\
\%\end{array}$ & YRF & $\begin{array}{l}\text { Yield } \\
\%\end{array}$ & $\begin{array}{l}\mathrm{RC} \\
\%\end{array}$ & $\begin{array}{l}\text { SE } \\
\%\end{array}$ & YRF \\
\hline 46.703 & 68.568 & 13.117 & 18.8 & 22.90 & 10.90 & 22.56 & 20.14 & 25.5 & 14.25 & 22.19 \\
\hline
\end{tabular}


From the analysis made from the data of coking grade of coal, the optimum points for the yield, recovery, Separation efficiency and yield reduction factor achieved when the collector, frother and pulp density were $46.703 \mathrm{~g} / \mathrm{t}, 65.568 \mathrm{~g} / \mathrm{t}$ and $13.117 \mathrm{~g} / \mathrm{t}$ respectively

\section{Analysis of Reject Coal by Froth Flotation}

Table 5. Thermal Grade 34\% ash

\begin{tabular}{llllllllll}
\hline \multicolumn{2}{l}{ Parameters } & \multicolumn{7}{c}{ Thermal Grade $(34 \%$ Ash) } \\
\hline Run & Collector $(\mathrm{g} / \mathrm{t})$ & Frother $(\mathrm{g} / \mathrm{t})$ & Pulp D $(\%)$ & Yield $(\%)$ & RC $(\%)$ & SE $(\%)$ & ARF & YRF & Time $(\mathrm{s})$ \\
\hline 1 & 39.3 & 61.8 & 12.5 & 3.2 & 8.22 & 6.76 & 2.40 & 43 \\
2 & 49.5 & 61.8 & 12.5 & 0.7 & 1.80 & 1.48 & 2.46 & 10 \\
3 & 39.3 & 68.8 & 12.5 & 3.0 & 7.71 & 6.33 & 2.41 & 40 \\
4 & 49.5 & 68.8 & 12.5 & 2.7 & 6.94 & 5.70 & 2.41 & 40 \\
5 & 39.3 & 65.3 & 10.0 & 2.6 & 6.68 & 5.49 & 2.42 & 20 \\
6 & 49.5 & 65.3 & 10.0 & 3.0 & 7.71 & 6.33 & 2.41 & 30 \\
7 & 39.3 & 65.3 & 15.0 & 3.3 & 8.48 & 6.97 & 54.25 & 2.40 & 46 \\
8 & 49.5 & 65.8 & 15.0 & 2.5 & 6.42 & 5.28 & 2.42 & 21 \\
9 & 44.4 & 61.8 & 10.0 & 3.1 & 7.96 & 6.55 & 2.40 & 22 \\
10 & 44.4 & 68.8 & 10.0 & 3.2 & 8.22 & 6.76 & 2.40 & 21 \\
11 & 44.4 & 61.8 & 15.0 & 3.7 & 9.51 & 7.81 & 2.39 & 34 \\
12 & 44.4 & 68.8 & 15.0 & 3.9 & 10.02 & 8.24 & 2.38 & 43 \\
13 & 44.4 & 65.3 & 12.5 & 3.8 & 9.76 & 8.02 & 2.39 & 21 \\
14 & 44.4 & 65.3 & 12.5 & 3.7 & 9.51 & 7.81 & 2.39 & 31 \\
\hline 15 & 44.4 & 65.3 & 12.5 & 3.9 & 10.02 & 8.24 & 2.38 & 37 \\
\hline
\end{tabular}

From the table above shows that the highest recovery attained when the frother and specific gravity were at the maximum values. This indicates that as frother dosage increase the recovery also increase while there is no much effect on the collector dosage.

Table 6. Optimum points for thermal grade ( $34 \%$ ash) by froth flotation

\begin{tabular}{llllll}
\hline Parameters & \multicolumn{5}{l}{ Thermal grade (34\% ash) } \\
\hline $\begin{array}{l}\text { Collector } \\
\mathrm{g} / \mathrm{t}\end{array}$ & $\begin{array}{l}\text { Frother } \\
\mathrm{g} / \mathrm{t}\end{array}$ & $\begin{array}{l}\text { Pulp Density } \\
\%\end{array}$ & $\begin{array}{l}\text { Yield } \\
\%\end{array}$ & $\begin{array}{l}\text { Recovery of Combustible } \\
\%\end{array}$ & $\begin{array}{l}\text { Separation Efficiency } \\
\%\end{array}$ \\
\hline 40.808 & 64.148 & 13.677 & 3.780 & 9.711 & 7.981 \\
\hline
\end{tabular}

The optimum points for the yield, recovery and Separation efficiency indicated in table 4 above. It shows that the optimum point for collector and frother concentration are $40.808 \mathrm{~g} / \mathrm{t}$ and $64.148 \mathrm{~g} / \mathrm{t}$ respectively, and the pulp density is $13.677 \%$.

\section{Mozley Results}

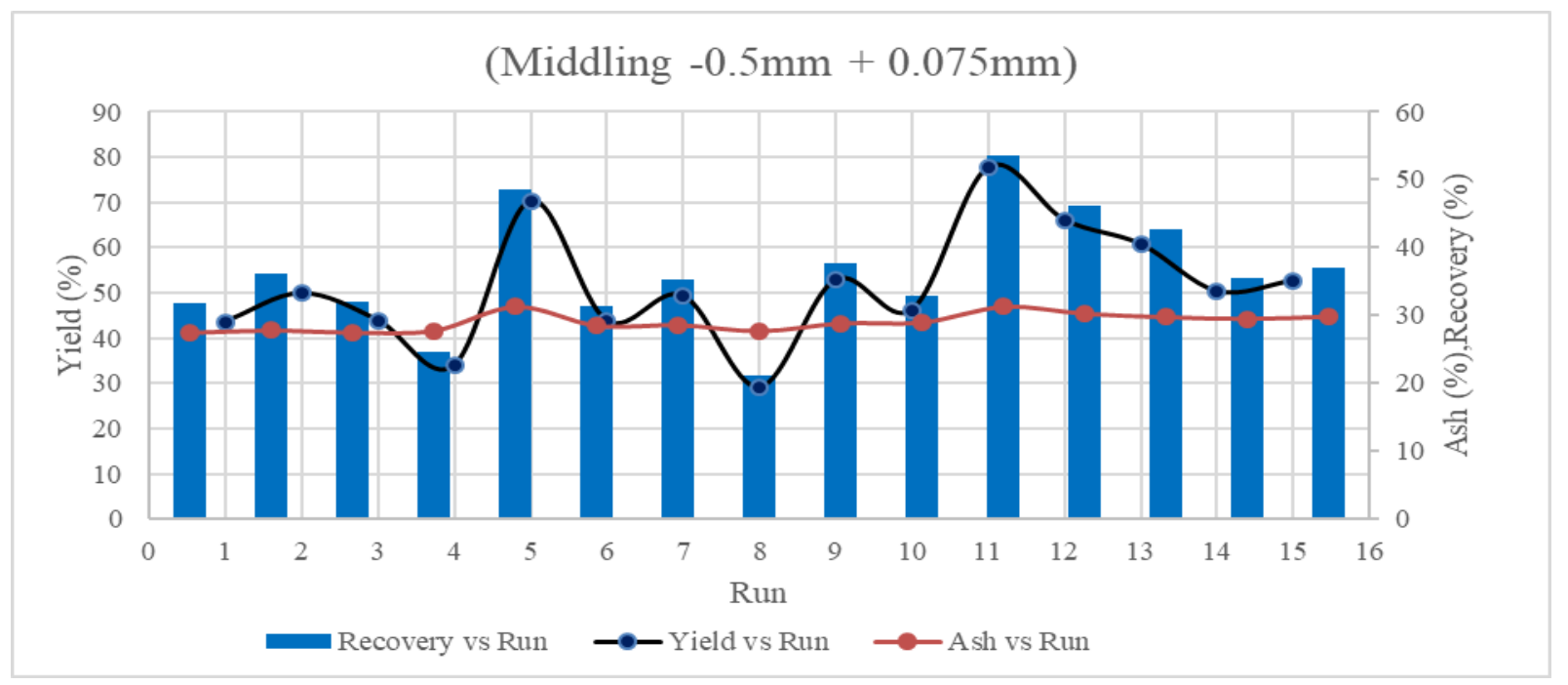

Figure 3. Recovery and yield for size ranges from $-0.5 \mathrm{~mm}$ to $+0.075 \mathrm{~mm}$

The graph of $-0.5 \mathrm{~mm}+0.075 \mathrm{~mm}$ shows the lowest ash attained was $27.46 \%$ at run 8 with recovery and yield of $21.09 \%$ and $27.07 \%$ respectively. 
Table 7. Optimum points for the middling sample ranging from $-1 \mathrm{~mm}$ to $+0.075 \mathrm{~mm}$

\begin{tabular}{lllllllll}
\hline Parameters & \multicolumn{7}{c}{$(-1 \mathrm{~mm}+0.075 \mathrm{~mm})$} \\
\hline Amplitude & Water flow rate & Wash time & Ash & Yield & RC & SE & ARF & YRF \\
inch & $\mathrm{ml} / \mathrm{m}$ & $\mathrm{s}$ & $\%$ & $\%$ & $\%$ & $\%$ & & \\
\hline 1.593 & 798.382 & 35.561 & 29.033 & 36.883 & 42.16 & 14.785 & 18.652 & 11.25 \\
\hline
\end{tabular}

The maximum point for the analysis is at amplitude of 1.593-inch, water flow rate of $798.382 \mathrm{ml} / \mathrm{m}$ and wash time 35.561 seconds, the recovery of combustible and yield are 42.16 and $36.88 \%$ respectively.

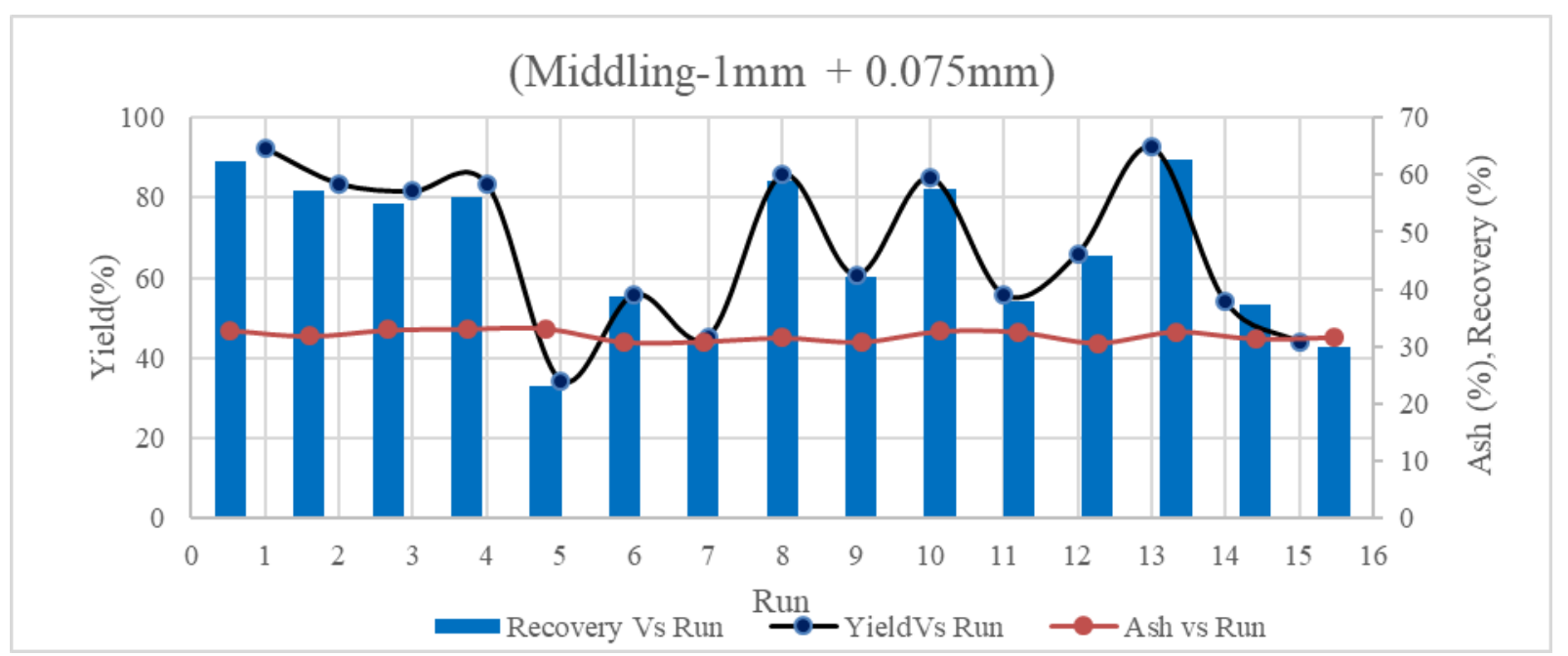

Figure 4. Graph of Yield and ash against Runs for Middling $(-1 \mathrm{~mm}+0.075 \mathrm{~mm})$

The graph of $-1 \mathrm{~mm}+0.075 \mathrm{~mm}$ indicates that the lowest ash attained at $30.58 \%$ at run 12 with recovery and yield of $45.8 \%$ and $65.93 \%$ respectively.

Table 7. Optimum points for the middling sample ranging from $-1 \mathrm{~mm}$ to $+0.075 \mathrm{~mm}$

\begin{tabular}{|c|c|c|c|c|c|c|c|c|}
\hline Parameters & & & $-1 m m$ & $0.105 \mathrm{mn}$ & & & & \\
\hline Amplitude & Water flow rate & Wash time & Ash & Yield & $\mathrm{RC}$ & $\mathrm{SE}$ & ARF & YRF \\
\hline inch & $\mathrm{ml} / \mathrm{m}$ & $\mathrm{S}$ & $\%$ & $\%$ & $\%$ & $\%$ & & \\
\hline 1.408 & 485.738 & 38.367 & 32.605 & 33.693 & 36.19 & 6.667 & 12.938 & 14.19 \\
\hline
\end{tabular}

The table above shows, the maximum point for the analysis is at amplitude is 1.408 -inch, water flow rate $485.738 \mathrm{ml} / \mathrm{m}$ and wash time 38.367 seconds, the recovery of combustible and yield is 36.19 and $33.693 \%$ respectively.

(Middling $-1 \mathrm{~mm}+0.105 \mathrm{~mm}$ )

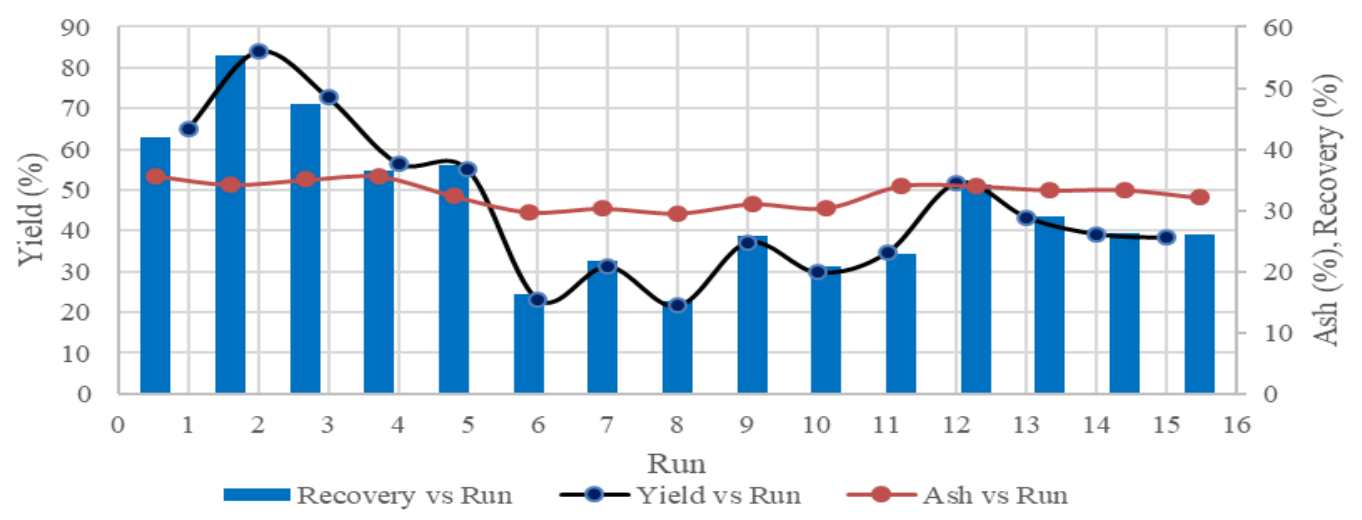

Figure 5. Graph of Yield and ash against runs for middling size range from $-1 \mathrm{~mm}$ to $+0.105 \mathrm{~mm}$

The graph shows the lowest ash attained at $29.5 \%$ at run 8 with recovery and yield of $15.25 \%$ and $21.55 \%$ respectively. 
Table 8. Optimum points for the middling sample ranging from $-2 \mathrm{~mm}$ to $+0.5 \mathrm{~mm}$

\begin{tabular}{lllllllll}
\hline Parameters & \multicolumn{7}{c}{$-2 m m$ to $+0.5 m m$} \\
Amplitude & Water flow rate & Wash time & Ash & Yield & RC & SE & ARF & YRF \\
inch & $\mathrm{ml} / \mathrm{m}$ & $\mathrm{S}$ & $\%$ & $\%$ & $\%$ & $\%$ & & \\
\hline 1.631 & 645.251 & 38.278 & 34.153 & 29.23731 .42 & 5.818 & 9.119 & 25.07 \\
\hline
\end{tabular}

The table above shows, the maximum point for the analysis is at amplitude of 1.63 -inch, water flow rate $645.25 \mathrm{ml} / \mathrm{m}$ and wash time of 38.278 seconds, the recovery of combustible and yield are 31.42 and $29.24 \%$ respectively

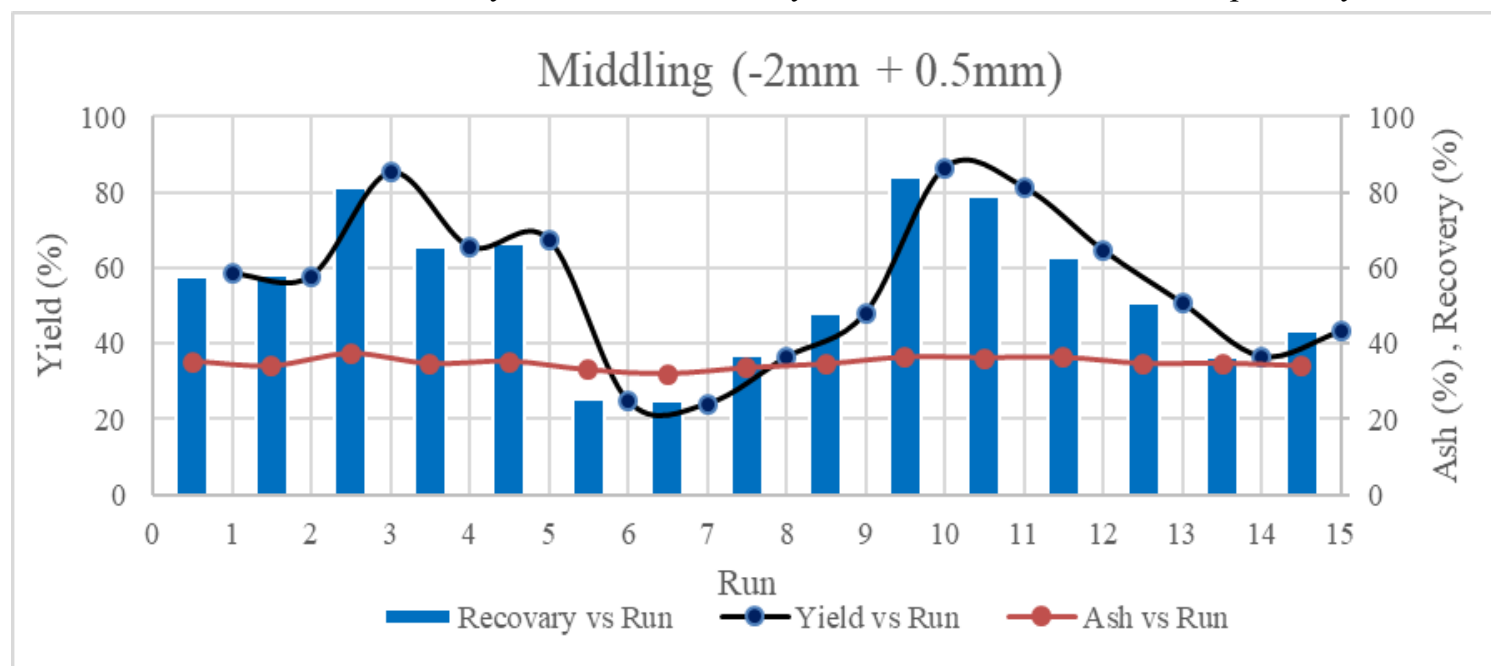

Figure 6. Graph of Yield and ash against runs for middling size range from $-2 \mathrm{~mm}$ to $+0.5 \mathrm{~mm}$

The graph shows the lowest ash attained at 31.91 at run 7 with recovery and yield of $24.92 \%$ and $24.04 \%$ respectively.

Table 10. Optimum points for the rejects sample ranging from $-0.5 \mathrm{~mm}$ to $+0.075 \mathrm{~mm}$

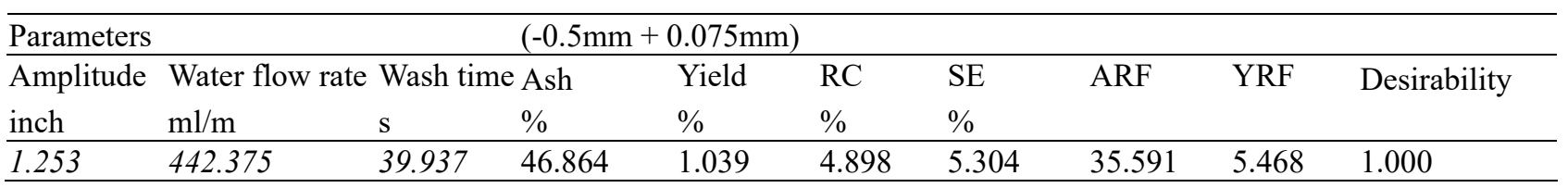

The table above shows the maximum point for the analysis at the amplitude of 1.253 -inch, water flow rate $442.375 \mathrm{ml} / \mathrm{m}$ and wash time of 39.375 seconds, the recovery of combustible and yield are 4.898 and $1.039 \%$ respectively.

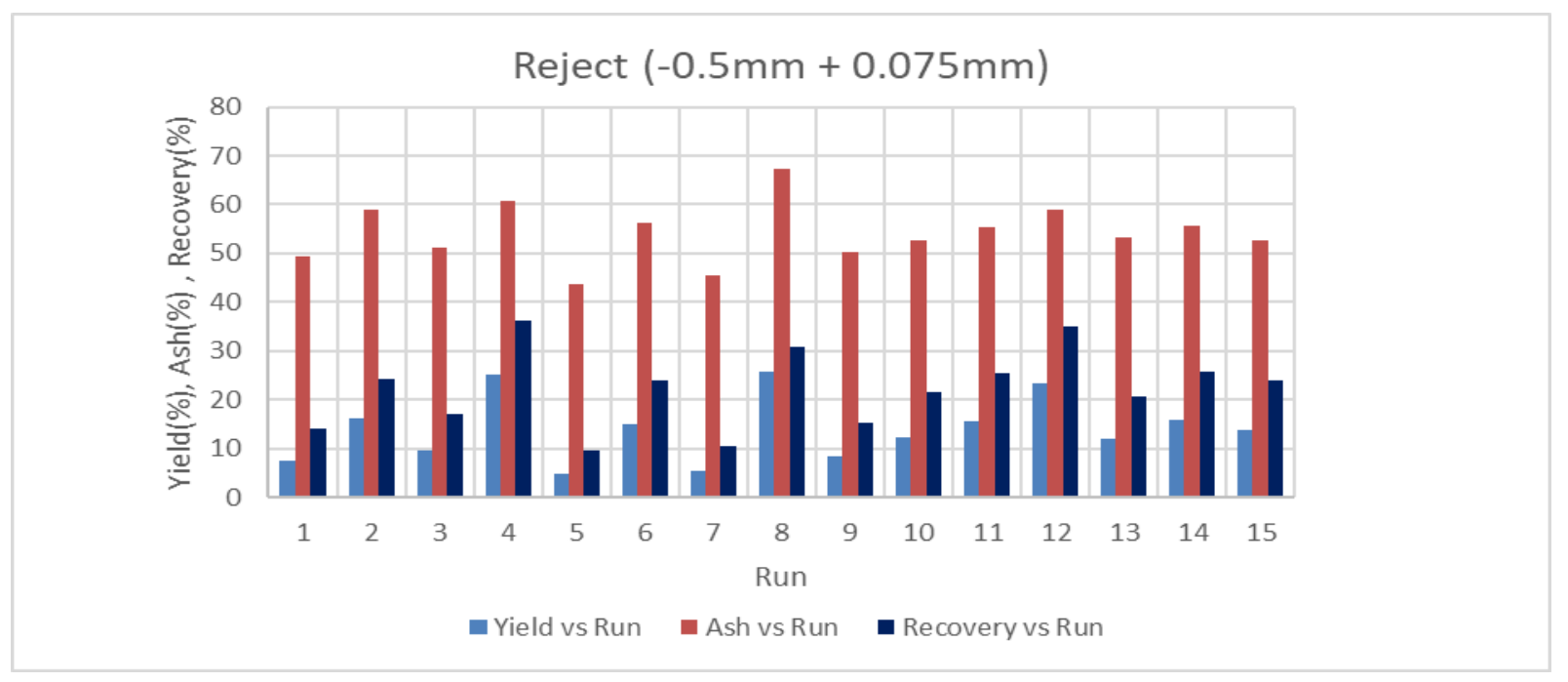

Figure 7. Graph of Yield and ash against runs for reject size range from $-0.5 \mathrm{~mm}$ to $+0.075 \mathrm{~mm}$

The graph shows the lowest ash attained at $43.81 \%$ at run 5 with recovery and yield of $9.63 \%$ and $4.7 \%$ respectively. 
Table 9. Optimum points for the rejects sample ranging from $-1 \mathrm{~mm}$ to $+0.075 \mathrm{~mm}$

\begin{tabular}{|c|c|c|c|c|c|c|c|c|}
\hline \multirow{2}{*}{$\frac{\text { Parameters }}{\text { Amplitude }}$} & \multicolumn{6}{|c|}{$(-1 \mathrm{~mm}+0.075 \mathrm{~mm})$} & \multirow{3}{*}{$\mathrm{ARF}$} & \multirow{3}{*}{ YRF } \\
\hline & Water flow rate & Wash & e Ash & Yield & $\mathrm{RC}$ & $\mathrm{SE}$ & & \\
\hline inch & $\mathrm{ml} / \mathrm{m}$ & $\mathrm{s}$ & $\%$ & $\%$ & $\%$ & $\%$ & & \\
\hline 1.608 & 605.317 & 33.609 & 59.569 & 7.252 & 10.390 & 4.278 & 18.788 & 7.035 \\
\hline
\end{tabular}

The table above shows, the maximum point for the analysis is at amplitude of 1.608 -inch, water flow rate $605.317 \mathrm{ml} / \mathrm{m}$ and wash time of 53.609 seconds, the recovery of combustible and yield are 10.390 and $7.252 \%$ respectively.

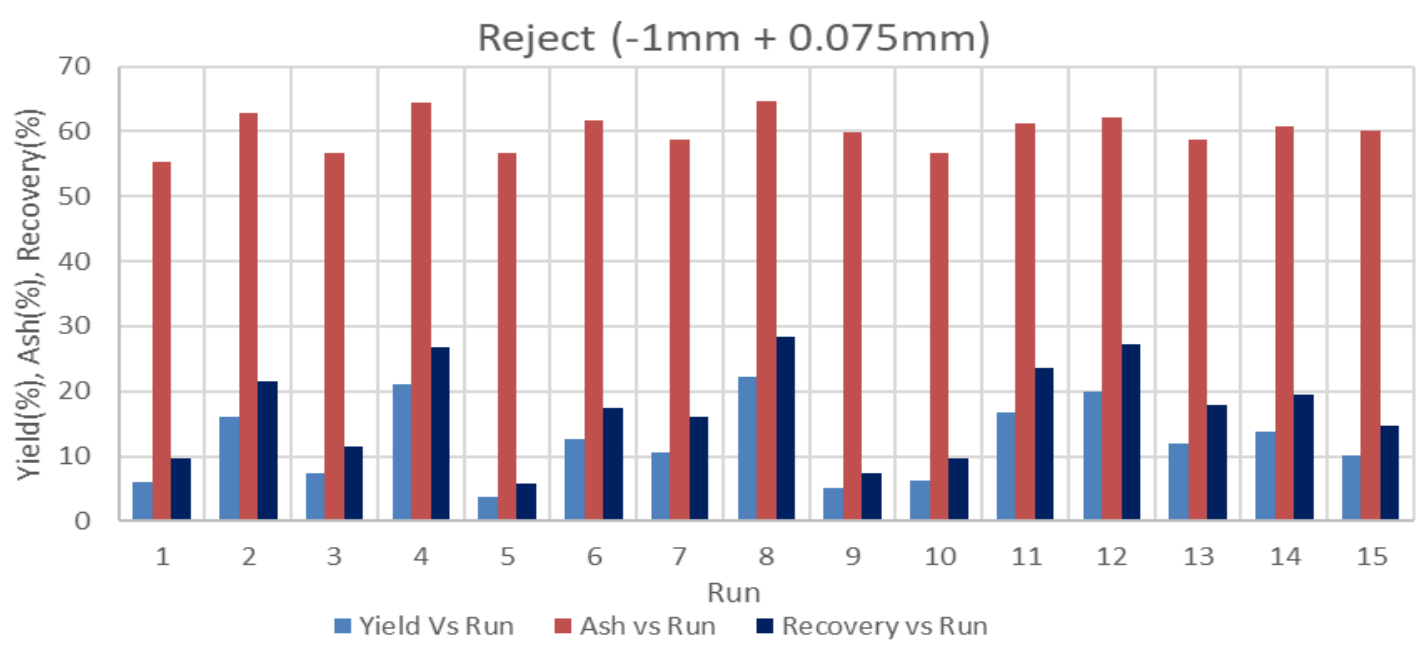

Figure 8. Graph of Yield and ash against runs for reject coal size range from $-1 \mathrm{~mm}$ to $+0.075 \mathrm{~mm}$

The graph shows the lowest ash is $55.36 \%$ at run 5 with recovery and yield of $5.76 \%$ and $3.69 \%$ respectively.

Table 10. Optimum points for the reject sample ranging from $-1 \mathrm{~mm}$ to $+0.105 \mathrm{~mm}$ )

\begin{tabular}{|c|c|c|c|c|c|c|c|c|}
\hline \multicolumn{3}{|l|}{ Parameters } & \multicolumn{6}{|c|}{$-1 \mathrm{~mm}$ to $+0.105 \mathrm{~mm}$} \\
\hline $\begin{array}{l}\text { Amplitude } \\
\text { inch }\end{array}$ & $\begin{array}{l}\text { Water flow rate } \\
\text { mlpm }\end{array}$ & $\begin{array}{l}\text { Wash time } \\
\mathrm{s}\end{array}$ & $\begin{array}{l}\text { Ash } \\
\%\end{array}$ & $\begin{array}{l}\text { Yield } \\
\%\end{array}$ & $\begin{array}{l}\mathrm{RC} \\
\%\end{array}$ & $\begin{array}{l}\text { SE } \\
\%\end{array}$ & ARF & YRF \\
\hline 1.626 & 541.093 & 30.093 & 62.524 & 10.931 & 15.063 & 5.711 & 13.594 & 8.800 \\
\hline
\end{tabular}

The table above shows, the maximum point for the analysis is at amplitude of 1.626 -inch, water flow rate $541.093 \mathrm{ml} / \mathrm{m}$ and wash time of 30.093 seconds, the recovery of combustible and yield are 15.063 and $10.931 \%$ respectively.

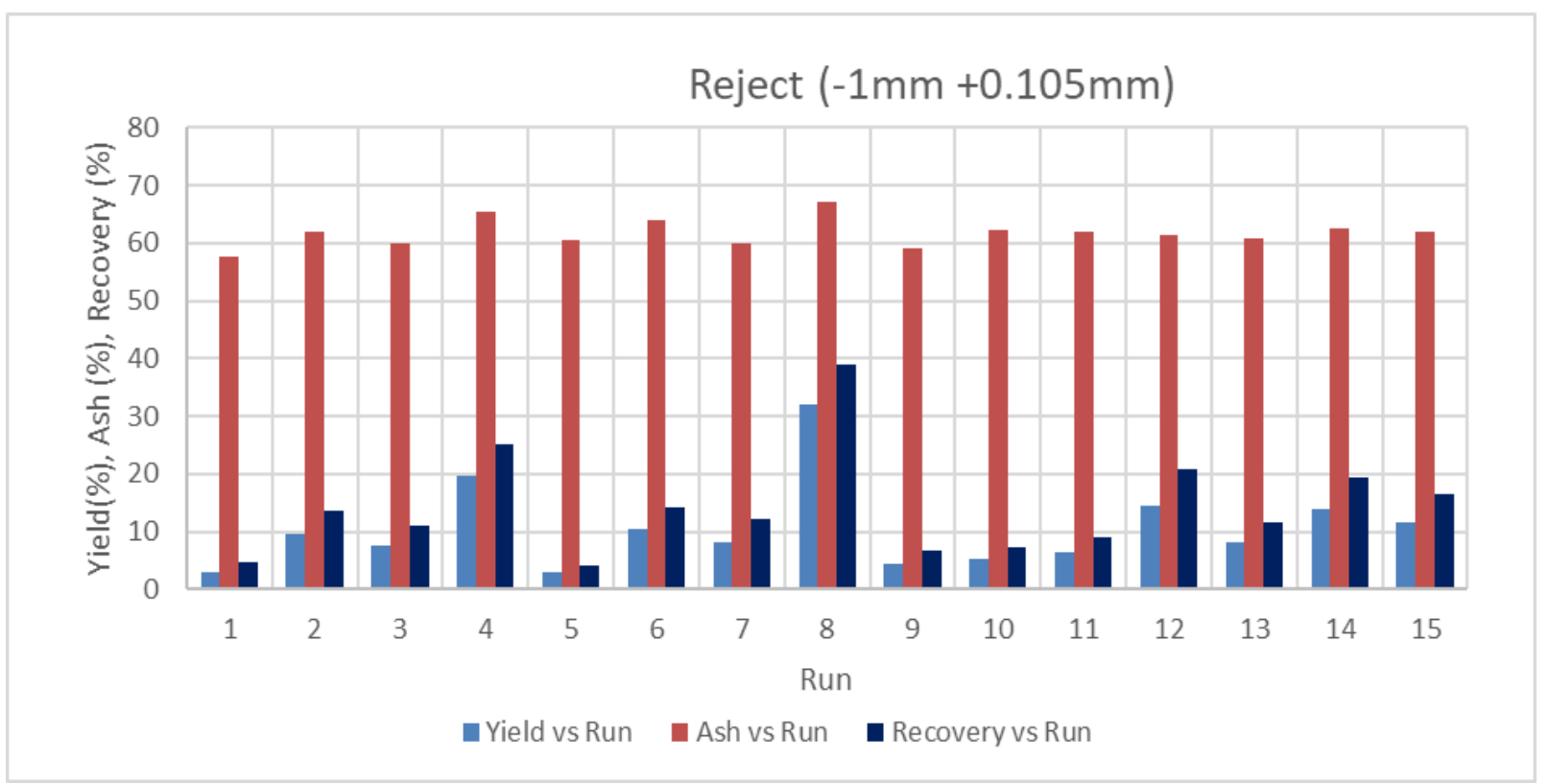

Figure 9. The graph of Yield and ash vs runs for rejects coal size ranging from $-1 \mathrm{~mm}$ to $0.105 \mathrm{~mm}$

The graph shows the lowest ash is $57.62 \%$ at run 5 with recovery and yield of $4.22 \%$ and $2.89 \%$ respectively. 
Table 11. Optimum points for the middling sample ranging from $-2 \mathrm{~mm}$ to $+0.5 \mathrm{~mm}$

\begin{tabular}{|c|c|c|c|c|c|c|c|c|}
\hline Parameters & & & $-2 m m t c$ & $5 \mathrm{~mm}$ & & & & \\
\hline Amplitude & Water flo & Wash time & Ash & Yield & $\mathrm{RC}$ & SE & ARF & YRF \\
\hline inch & $\mathrm{Ml} / \mathrm{m}$ & $\mathrm{s}$ & $\%$ & $\%$ & $\%$ & $\%$ & & \\
\hline 1.525 & 553.548 & 36.956 & 67.696 & 32.815 & 37.869 & 7.029 & 5.834 & 19.627 \\
\hline
\end{tabular}

The table above shows, the maximum point for the analysis is at amplitude of 1.525 -inch, water flow rate $553.548 \mathrm{ml} / \mathrm{m}$ and wash time of 36.956 seconds, the recovery of combustible and yield are 37.869 and $32.815 \%$ respectively.

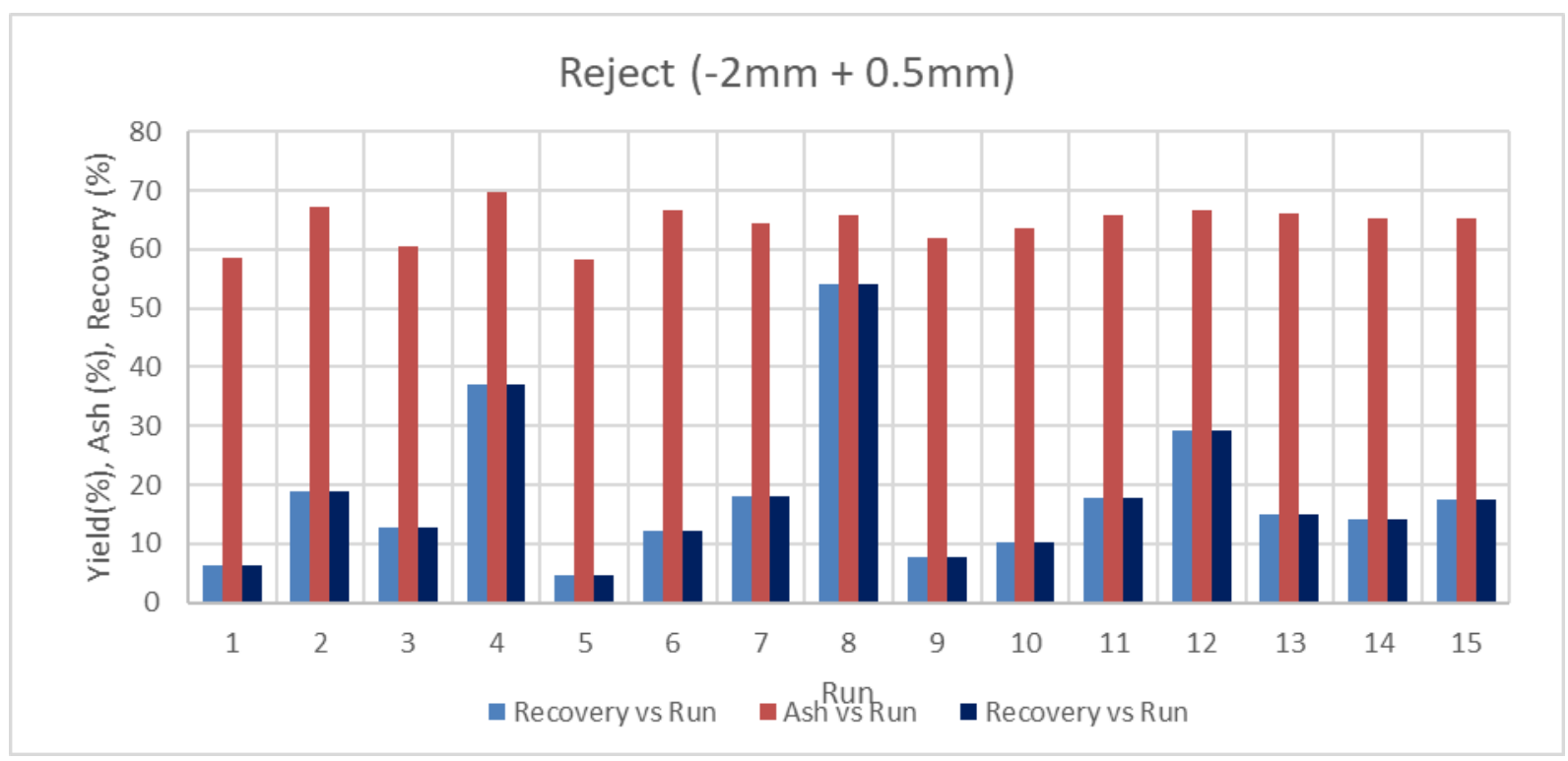

Figure 10. The graph of Yield and ash vs Runs for rejects coal size ranging from $-2 \mathrm{~mm}$ to $0.5 \mathrm{~mm}$

The graph shows the lowest ash is $58.29 \%$ at run 5 with recovery and yield of $4.61 \%$ and $3.2 \%$ respectively.

\section{Froth Flotation}

The ash contents for the middling sample treated by froth flotation decreases from $37 \%$ of the feed to $15.85 \%$ of clean coal at the reagent concentration of $49.5 \mathrm{~g} / \mathrm{t}$ collector, $65.3 \mathrm{~g} / \mathrm{t}$ frother and pulp density of $10 \%$. This decrease of ash is very significant to conclude that the investigation has achieved its objectives.

The regression analysis performed based on $21 \%$ (washery grade I) and $24 \%$ (washery grade II) to determine the parameters which will give the optimum point for the yield, ash, recovery of combustible, Separation efficiency and yield reduction factor. Therefore, froth flotation of middling sample observed that the optimum achieved at the independent variables of $46.703 \mathrm{~g} / \mathrm{t}, 68.568$ and $13.117 \%$ for the collector, frother and pulp density respectively. The dependent variables for washery grade II calculated based on the independent variables from optimum points which resulted to $18.8 \%, 22.9 \%, 10.9 \%$ and 22.56 for the yield, recovery of combustible, Separation efficiency and yield reduction factor respectively. For washery grade I the dependent variables calculated similarly to washery grade II and results were $20.1 \%$, $25.5 \%, 14.25 \%$ and $22.19 \%$ for the yield, recovery of combustible, Separation efficiency and yield reduction factor respectively.

Thermal grade ( $34 \%$ ash) was calculated from each run of reject froth flotation and deduced that the optimum point for the analysis was at $40.808 \mathrm{~g} / \mathrm{t}, 64.148 \mathrm{~g} / \mathrm{t}$ and $13.677 \%$ for collector, frother and solid concentration, which resulting to $3.78 \%, 9.77$ and 7.89 for yield, recovery of combustible and Separation efficiency.

It observed that the more the collector added the less the ash contents with less recovery while the more the frother the higher the mass pull with high ash contents.

Results from froth flotation of reject shown that there was a big reduction of ash values from $71 \%$ of feed to $28.88 \%$ of clean coal. This reduction is good and agree with obtaining coal which is suitable for thermal grade of less than $35 \%$ ash.

\section{Mozley Mineral Separation}

The Mozley Mineral Separation performed for the middling and reject sample based on variation of independent variables. The middling sample with the size range from $-1 \mathrm{~mm}$ to $+0.105 \mathrm{~mm}$ shown the best ash reduction of $29.5 \%$ with the yield of $21.6 \%$ of clean coal. Regression analysis performed for these range it gives the optimum independent variables of $1.40 \mathrm{inch}, 485.738 \mathrm{ml} / \mathrm{m}$ and 38.4 seconds for the amplitude, water flow rate and wash time respectively. The optimum 
point obtained was $33.605 \%, 33.69 \%$, and $36.69 \%$ for ash, yield and recovery respectively. From these results conclude that the experiments results do not varies with a big margin from the regression data.

For the reject sample, the best ash attained by mozley mineral Separation was $47 \%$ at the size range from $-0.5 \mathrm{~mm}$ to $+0.075 \mathrm{~mm}$ and the Ash obtained by regression was $46.86 \%$ at the recovery of $4.9 \%$ with the optimum points of $1.253 \mathrm{inch}$ for amplitude, 442.378 for water flow rate and 39.9 second for wash water. In conclusion the mozley mineral separator did not show good results for both middling and reject.

\section{References}

Brown, D. J. (1962). Coal Flotation, D. W., 518-538.

Dash, P. S., Lingam, R. K., Sriramoju, S. K., Suresh, A., Banerjee, P. K., \& Ganguly, S. (2015). Effect of elevated temperature and pressure on the leaching characteristics of Indian coals. Fuel, 140, 302-308. https://doi.org/10.1016/j.fuel.2014.09.110

Davis, D. H. (1948). Froth Flotation of Minus 48 Mesh Bituminous Coal Slurries, Trans. AIME 177, 320-337.

Decker, H. W., \& Hoffman, J. N. (1956). Coal Preparation, 1. The Penn State University, University Park, Pennsylvania.

Energy statistical data. (2018).

Gupta, O. P. (1990). Fuels, Furnaces and Refractories, Khanna Publishers, Bakaro.

Laros, T. J. (1977). Physical Desulfurization of Iowa Coal by Froth Flotation, IS-ICP-47, Iowa State University, Ames, Iowa. https://doi.org/10.2172/5364120

Luttrell, G. H., Honaker, R. Q., \& Phillips, D. I. (1995). Enhanced gravity separators: new alternatives for fine coal cleaning. In: Proceedings of the 12th International Coal Preparation Conference. Lexington, KY.

Luttrell, G. H., Venkatraman, P., Yoon, R. H. (1994). Development of a combined flotation/gravity Separation circuit for the fine coal cleaning. In: Proceedings of the $12^{\text {th }}$ International Coal Preparation Congress. Krakov, Poland.

Miller, K. J. (1975). Coal-pyrite flotation. Trans. AIME, 258, 30.

Rao, L. S., \& Bandopadhyay, P. (1992). Application of a mozley mineral separator for treatment of coal washery rejects. International Journal of Mineral Processing, 36, 137-150. https://doi.org/10.1016/0301-7516(92)90070-D

Reddy, et al. (2000). Recovery of coal fines from rejects by column flotation, reginal Research laboratory, Bhubaneswa, ISBN 81-87053-53-4, 213-221.

Suresh. (2015). Pilot scale demineralization study on coal flotation tailings and optimization of the operational parameters with modeling. International Journal of Mineral Processing, 145, 23-31. https://doi.org/10.1016/j.minpro.2015.11.004

Zimmerman, R. E. (1964). Froth Flotation in Modern Coal Preparation Plants. J. Mining Congress, 26-32.

\section{Copyrights}

Copyright for this article is retained by the author(s), with first publication rights granted to the journal.

This is an open-access article distributed under the terms and conditions of the Creative Commons Attribution license which permits unrestricted use, distribution, and reproduction in any medium, provided the original work is properly cited. 